\title{
MINAT PERILAKU PENGGUNAAN YOUTUBE SEBAGAI SUMBER PEMBELAJARAN DENGAN PENDEKATAN TAM
}

\author{
Nastiti Pertiwi \\ nastitipertiwi@student.telkomuniversity.ac.id \\ Osa Omar Sharif \\ Universitas Telkom
}

diterima: 29/3/2018; direvisi: 22/11/2018; diterbitkan: 27/2/2019

\begin{abstract}
This study aims to determine factors that influence the use of information resources from Youtube for learning purposes. This study is TAM model to identify behavioral intention of Youtube as a learning resource. It aims to know the effects of Perceived Ease of Use towards Perceived Usefulness, Perceived Ease of Use towards Attitude to Use, Perceived Usefulness towards Attitude to Use, and Attitude towards Use towards Behavioral Intention. Also, to know whether this model fits to the studied data. Samples comes from 155 respondents. This research uses Sctructural Equation Modelling. The result of this research showed that Perceived Ease of Use variable proved affects towards Perceived Usefulness, Perceived Ease of Use variable unproved affects towards Attitude to Use, Perceived Usefulness variable proved affects towards Attitude to Use, and Attitude to Use proved affects towards Behavioral Intention. The results on the model tested indicates that this model fits to the population.
\end{abstract}

Keywords: youtube; tecnology acceptance model (TAM); structural equation modeling

\begin{abstract}
Abstrak
Penelitian ini untuk mengetahui faktor-faktor yang memengaruhi penggunaan sumber informasi seperti Youtube untuk tujuan pembelajaran. Penelitian ini menggunakan model TAM yang bertujuan untuk mengetahui minat penggunaan Youtube sebagai sumber pembelajaran yang dimana melihat pengaruh Perceived Ease of Use terhadap Perceived Usefulness, pengaruh Perceived Ease of Use terhadap Attitude to Use, pengaruh Perceived Usefulness terhadap Attitude to Use, dan pengaruh Attitude to Use terhadap Behavioral Intention. Serta untuk mengetahui apakah model yang digunakan fit untuk populasi yang diteliti. Sampel pada penelitian ini melibatkan 155 responden. Penelitian ini menggunakan Sctructural Equation Modelling (SEM). Hasil penelitian ini menunjukkan bahwa variabel Perceived Ease of Use terbukti berpengaruh terhadap Perceived Usefulness, variabel Perceived Ease of Use tidak terbukti berpengaruh terhadap Attitude to Use, variabel Perceived Usefulness terbukti berpengaruh terhadap Attitude to Use, dan variabel Attitude to Use terbukti berpengaruh terhadap Behavioral Intention. Kemudian, untuk model yang digunakan pada penelitian ini fit dengan populasi.
\end{abstract}

Kata Kunci: youtube; tecnology acceptance model (TAM); structural equation modeling 


\section{PENDAHULUAN}

Dewasa ini perkembangan teknologi dapat memicu perubahan di bidang pendidikan. Kegiatan belajar mengajar dibatasi oleh lokasi geografis antara guru dan pelajar. Munculnya teknologi dapat melonggarkan keterbatasan waktu dan ruang tersebut. Jumlah pengguna internet yang mengakses konten pendidikan menurut APJII (2016) sebesar 93,8\%. Hal ini menggambarkan bahwa banyak pelajar, mahasiswa, maupun civitas akademik lainnya mengakses konten pendidikan untuk keperluan belajar mengajar. Selain buku-buku literatur, tutorial dan lain-lain, Youtube memungkinkan pelajar untuk bebas menentukan kecepatan belajar mereka. Meski Youtube populer sebagai media hiburan, namun Youtube telah menjadi sumber belajar dan dianggap sebagai alternatif untuk menyampaikan materi pengajaran. Youtube sebagai sumber pembelajaran informal telah diperiksa sebagai bagian dari tantangan keaksaraan digital yang dihadapi oleh organisasi (Tan, 2013) dalam (Chintalapati dan Daruri, 2016). Studi ini telah memeriksa pertanyaan tentang pembelajaran yang berlangsung di ruang digital dan bagaimana siswa terlibat dengan sumber daya yang tersedia untuk belajar. Sebuah studi tentang peran Youtube dalam rangkaian koleksi media di perpustakaan akademis telah mengidentifikasi kemungkinan yang menarik (Cho, 2013) dalam (Chintalapati dan Daruri, 2016). Youtube digunakan oleh mahasiswa untuk mengambil konten untuk mendukung pembelajaran kolaboratif (Hrastinski dan Aghaee, 2012) dalam (Chintalapati dan Daruri, 2016).

Hal yang menunjang peneliti untuk menggunakan dosen Universitas Telkom sebagai objek penelitian ini adalah adanya fitur dimana dosen dapat menyisipkan link video Youtube pada e-learning (IDEA) milik Universitas Telkom. Selain itu, untuk membuktikan bahwa dosen-dosen menggunakan Youtube sebagai sumber pembelajaran, peneliti melakukan wawancara pada satu hingga dua orang dosen per fakultas.

Inti dari hasil wawancara dosen-dosen tersebut yaitu: rata-rata jumlah video yang digunakan untuk pembelajaran adalah 117 video, rata-rata jumlah video yang digunakan untuk penelitian 85 video yang digunakan selama dosen-dosen tersebut mengajar. Dari rata-rata tersebut dapat disimpulkan bahwa banyak video yang digunakan sebagai sumber belajar. Namun, terdapat perbedaan yang signifikan antara jumlah terkecil yaitu nol video dan jumlah terbanyak yaitu 500 video yang digunakan untuk pembelajaran. Hal tersebut menggambarkan bahwa perlu adanya penelitian tentang bagaimana perilaku pengguna Youtube tersebut dapat menerima penggunaan teknologi dari Youtube sebagai sumber pembelajaran (Tabel 1).

Kebutuhan untuk mempelajari konsep baru dan memahami dinamika perubahan lingkungan bisnis dipenuhi melalui video yang di-host di Youtube merupakan umpan balik dari banyak individu. Namun, tidak ada bukti empiris mengenai faktor-faktor yang mempengaruhi penggunaan sumber informasi seperti Youtube untuk tujuan pembelajaran (Chintalapati dan Daruri, 2016). Penelitian ini ingin mengukur minat dari penggunaan Youtube sebagai sumber pembelajaran dengan menggunakan metode TAM untuk meneliti faktor-faktor yang mempengaruhi, serta dapat melihat apakah model ini cocok digunakan untuk populasi yang diteliti yaitu dosen Universitas Telkom.

Alasan menggunakan metode Technology Acceptance Model (TAM) karena TAM dapat menjelaskan penerimaan suatu teknologi. Menurut Wibowo (2008) dalam (Bangkara \& Mimba, 2016) TAM merupakan suatu model yang dibangun untuk menganalisis dan memahami faktor-faktor yang mempengaruhi diterimanya penggunaan teknologi. Teori ini pertama kali dikenalkan oleh Davis (1986). Teori TAM dikembangkan dari Theory of Reasoned Action (TRA) oleh Ajzen dan Fishbein (1980) (Hartono, 2007:111). Setiap teori yang memenuhi tiga karakteristik berikut akan menjadi metode populer untuk memahami situasi yang kompleks, yaitu: parsimoni, verifiabilitas dan generalisasi. Parsimony adalah karakteristik yang sederhana atau kurang variabel; Verifiability adalah dukungan data; Generalisasi adalah tentang penggunaan teori di berbagai bidang. TAM memenuhi karakteristik ini dan oleh karenanya menjadi sangat populer (Lee et, al., 2003) dalam (Chintalapati dan Daruri, 2016). Hal ini ditemukan menjadi model untuk lebih menjelaskan perilaku individu yang mungkin cenderung positif terhadap teknologi (Moon dan Kim, 2001) dalam (Chintalapati dan Daruri, 2016). dan karena itu TAM dipilih sebagai dasar dari penelitian ini. Penulis menggunakan metode TAM khususnya model yang digunakan Chintalapati \& Daruri (2016) untuk meneliti minat perilaku penggunaan Youtube sebagai sumber pembelajaran. Chintalapati \& Daruri (2016) mengemukakan bahwa minat perilaku untuk menggunakan suatu teknologi dapat dijelaskan dengan tiga konstruk, yaitu PEU, PU, dan ATU. Perkembangan selanjutnya dari TAM, BI digunakan sebagai variabel baru yang akan secara langsung dipengaruhi oleh PU dan ATU Davis et al. (1989) dalam (Pinho dan Soares, 2011).

Menurut Davis et al. (1989) dalam (Rukmiyati dan Budiartha, 2016) Perceived Ease of Use (PEU) merupakan tingkat seberapa besar teknologi komputer dirasakan relatif mudah untuk dipahami dan digunakan. Perceived of usefulness (persepsi penggunaan) Menurut Davis et al. (1989) dalam (Rukmiyati dan Budiartha, 2016) Perceived of usefulness (PU) merupakan suatu tingkatan dimana seseorang percaya bahwa penggunaan suatu subyek tertentu akan dapat meningkatkan prestasi kerja orang tersebut. Attitude to Use (ATU) menurut Davis et al. (1989) dalam (Bangkara \& Mimba, 2016) attitude toward using (sikap terhadap penggunaan) 
merupakan perasaan positif atau negatif dari seseorang jika harus melakukan perilaku yang akan ditentukan. Behavioral Intention (BI) merupakan suatu minat atau keinginan untuk melakukan perilaku. Minat perilaku (BI) ini belum berupa perilaku, karena perilaku itu sendiri dilakukan karena individual memiliki minat atau keinginan untuk melakukannya (Hartono, 2007:25-26). Variabel yang digunakan pada penelitian ini adalah variabel Perceived Ease of Use sebagai variabel independen (eksogen) dan menggunakan variabel Perceived Usefulness, Attitude to Use, Behavioral Intention sebagai variabel dependen (endogen). Kerangka pemikiran ditunjukkan pada Gambar 1.

Berdasarkan kerangka penelitian di atas, hipotesis penelitian ini dapat diuraikan sebagai berikut: (1) Perceived Ease of Use berpengaruh terhadap Perceived Usefulness. (2) Perceived Ease of Use berpengaruh terhadap Attitude to Use Youtube. (3) Perceived Usefulness berpengaruh terhadap Attitude to Use Youtube. (4) Attitude to Use berpengaruh terhadap Behavioral Intention.

\section{METODE}

Metode penelitian yang digunakan dalam penelitian ini adalah kuantitatif dengan tujuan penelitian adalah deskriptif dan korelasional. Berdasarkan tipe penyelidikan penelitian ini adalah penelitian kausal. Dalam penelitian ini peneliti tidak mengintervensi data dan waktu pelaksanaan penelitian ini adalah cross sectional. Populasi pada penelitian ini adalah dosen tetap Universitas Telkom Bandung. Jumlah dosen tetap pada Universitas Telkom menurut Igracias terdapat 733 orang (SDM Universitas Telkom, 2018). Ukuran sampel minimum 150: model yang berisi konstruksi tujuh atau lebih sedikit, komunalitas sederhana $(0,5)$ dan tidak ada konstruksi yang tidak dikenali (underidentifined construct) Hair et, al., (2010). Minimum sampel pada penelitian ini adalah 150 karena terdapat nilai komunalitas sebesar 0,5 pada indikator. Pengumpulan data dilakukan pada dosen Universitas Telkom yang menggunakan Youtube sebagai sumber pembelajaran sebanyak 155 responden. Penelitian ini menggunakan metode non-probability sampling dengan tipe quota sampling yang dibedakan berdasarkan kuota per fakultas.

Teknik analisis data yang digunakan adalah structural equation model (SEM) khususnya Partial Least Square (PLS-SEM). PLS-SEM bertujuan untuk menguji hubungan prediktif antar konstruk dengan melihat apakah ada hubungan atau pengaruh antar konstruk tersebut (Haryono, 2017:13). Alasan menggunakan PLS-SEM pada penelitian ini adalah jumlah sampel pada penelitian ini tergolong sedikit yaitu 155 responden. Serta hasil dari uji normalitas menyatakan bahwa data penelitian ini tidak berdistribusi normal. VB-SEM memperbolehkan dilanggarnya asumsi multivariate normality (non-parametrik) (Haryono, 2017:14). Skala pengukuran yang digunakan dalam penelitian ini adalah skala likert. TAM merupakan konstruk unidimensional, yaitu konstruk yang dibentuk langsung dari manifest (indikator) variabelnya dengan arah indikatornya dapat berbentuk reflective maupun formative (Haryono, 2017). Melihat fungsi Youtube sebagai sumber pembelajaran, maka peneliti mengadaptasi indikator penelitian dari Chintalapati dan Haruri. Secara keseluruhan indikator yang digunakan terdapat pada Tabel 2 .

\section{HASIL}

Berdasarkan hasil penelitian, karakteristik reponden pada penelitian ini dibagi menjadi dua pertanyaan screening question dan empat pertanyaan berdasarkan demografi. Pada pertanyaan screening question, terdapat $96 \%$ dari 162 responden atau 155 orang yang menjawab pernah menggunakan Youtube sebagai sumber pembelajaran. Pada pertanyaan screening question kedua didominasi oleh responden yang menggunakan lebih dari sepuluh video Youtube sebagai sumber pembelajaran sebesar $45 \%$ dari 155 orang. Pada pertanyaan demografi berdasarkan jenis kelamin didominasi oleh laki-laki yang memiliki persentase sebesar 64\% dari 155 orang. Pada pertanyaan demografi berdasarkan usia didominasi oleh 30-39 tahun yang memiliki persentase sebesar $46 \%$ dari 155 responden. Pada pertanyaan demografi berdasarkan pendidikan terakhir didominasi oleh magister yang memiliki persentase $90 \%$ dari 155 responden. Pada pertanyaan demografi berdasarkan status didomniasi oleh dosen tetap biasa yang memiliki persentase sebesar $78 \%$ dari 155 responden.

Hasil analisis deskriptif berdasarkan hasil penilaian dosen Universitas Telkom mengenai Perceived Ease of Use Youtube sebagai sumber pembelajaran dengan hasil 83,09\% masuk dalam kategori baik, dengan kata lain Youtube mudah untuk digunakan sebagai sumber pembelajaran. Selanjutnya, hasil penilaian dosen Universitas Telkom mengenai Perceived Usefulness Youtube sebagai sumber pembelajaran dengan hasil 79,45\% masuk dalam kategori baik, dengan kata lain Youtube bermanfaat sebagai sumber pembelajaran. Selanjutnya, hasil penilaian dosen Universitas Telkom mengenai Attitude to Use atau sikap dalam menggunakan Youtube dengan hasil 74,94\% masuk kategori baik. Selanjutnya, hasil penilaian dosen Universitas Telkom mengenai Behavioral Intention Youtube sebagai sumber pembelajaran dengan hasil 72,85\% masuk kategori baik, dengan kata lain pengguna Youtube memiliki minat yang tinggi untuk menggunakan Youtube sebagai sumber pembelajaran.

Berdasarkan hasil model pengukuran (Outer model) untuk convergent validity dilihat dari nilai loading factor maka indikator yang valid (lebih besar sama dengan 0,7) adalah PEU1, PEU2, PEU3, PU1, PU2, PU3, PU7, 
ATU1, ATU2, ATU3, ATU5, ATU6, BI1, BI2, BI3, BI4, BI5. Sedangkan melihat nilai validity dari AVE (Average Variance Extracted) untuk PEU $=0,65 ; \mathrm{PU}=0,54$; $\mathrm{ATU}=0,55 ; \mathrm{BI}=0,59$ dimana semua nilai tersebut dinyatakan valid karena lebih dari 0,5 . Selanjutnya untuk discriminant validity yang diukur dengan nilai cross loading menyatakan bahwa seluruh indikator dinyatakan valid karena lebih dari sama dengan 0,7.

Berdasarkan hasil outer model untuk reliabilitas yang diukur dengan composite reliability, masingmasing nilai variabel tersebut dalah untuk $\mathrm{PEU}=0,85$; $\mathrm{PU}=0,83$; $\mathrm{ATU}=0,86 ; \mathrm{BI}=0,88$. Seluruh variabel dinyatakan reliabel karena lebih dari 0,8 . Selanjutnya untuk reliabilitas yang diukur dengan nilai cronbach's alpha, masing-masing nilai variabel tersebut dalah untuk $\mathrm{PEU}=0,75 ; \mathrm{PU}=0,72 ; \mathrm{ATU}=0,80 ; \mathrm{BI}=0,82$. Seluruh variabel dinyatakan reliabel karena lebih dari 0,8 .

Selanjutnya berdasarkan hasil inner model dilihat dari hasil r-square dapat disimpulkan model ini mengindikasikan moderat. Pada variabel Attitude to Use memiliki nilai 0,39 yang mengindikasikan model tersebut moderat. Pada variabel Behavioral Intention yang memiliki nilai 0,56 mengindikasikan model tersebut moderat. Untuk variabel Perceived Usefulness memiliki nilai 0,47 yang mengindikasikan model tersebut moderat.

\section{PEMBAHASAN}

Berdasarkan hasil analisis hipotesis yang telah diuji oleh peneliti pada Tabel 3 pada H1 terbukti terdapat pengaruh antara variabel Perceived Ease of Use terhadap Perceived Usefulness, hal ini menunjukkan bahwa persepsi kemudahan dalam menggunakan Youtube berpengaruh terhadap persepsi kegunaan dari Youtube sebagai sumber pembelajaran. Jika dibandingkan dengan jurnal terdahulu (Pinho dan Soares, 2011), hasil analisis hipotesis peneliti sama dengan hasil analisis hipotesis pada jurnal terdahulu yaitu variabel Perceived Ease of Use berpengaruh terhadap Perceived Usefulness.

Untuk mengetahui nilai mediasi maka dapat dilihat dari perhitungan total effect (TE) dari path coefficients antara hubungan PEU $\rightarrow$ ATU ditambah dengan $\mathrm{PEU} \rightarrow \mathrm{PU} \rightarrow \mathrm{ATU}$.

$$
\begin{aligned}
& \mathrm{TE}=\mathrm{DE}+\mathrm{IE} \\
& \mathrm{TE}=0,069+0,395 \\
& \mathrm{TE}=0,464
\end{aligned}
$$

Dari perhitungan di atas didapatkan nilai path coefficients TE sebesar 0,462 dan pada hasil Total effect memiliki nilai t-statistic 5,104 > 1,96, maka dapat disimpulkan bahwa PU merupakan full mediator yang memediasi hubungan antar PEU dan ATU. Meskipun pada hubungan PEU $\rightarrow$ ATU tidak terbukti berpengaruh, namun hubungan PEU ke ATU melalui PU terbukti berpengaruh. Pada hasil analisis $\mathrm{H} 2$, variabel Perceived Ease of Use tidak terbukti berpengaruh terhadap Attitude to Use, hal ini menunjukkan bahwa persepsi kemudahan dalam menggunakan Youtube tidak berpengaruh pada sikap untuk menggunakan Youtube sebagai sumber pembelajaran. Temuan ini mendukung temuan peneliti lain yaitu Tarhini et al. (2015) dan (Agarwal dan Prasad, 1998; Chau dan Hu, 2002; Davis, Bagozzi dan Warshaw, 1989) dalam (Tarhini et, al., 2015) yang menunjukkan bahwa sikap yang dirasakan saat menggunakan hanya akan menjadi penting selama tahap awal adopsi. Hal ini mungkin karena sebagian besar responden berpengalaman menggunakan Youtube yang sebagian besar mengurangi efek kemudahan penggunaan.

Pada hasil analisis H3, variabel Perceived Usefulness terbukti berpengaruh terhadap Attitude to Use, hal ini menunjukkan bahwa persepsi pengguna mengenai kegunaan Youtube berpengaruh pada sikap untuk menggunakan Youtube sebagai sumber pembelajaran. Jika dibandingkan dengan jurnal terdahulu (Pinho dan Soares, 2011) hasil analisis hipotesis peneliti sama dengan hasil analisis hipotesis pada jurnal terdahulu yaitu variabel Perceived Usefulness memiliki pengaruh terhadap Attitude to Use.

Pada hasil analisis H4, variabel Attitude to Use terbukti berpengaruh terhadap Behavioral Intention, hal ini menunjukkan bahwa sikap dalam menggunakan Youtube berpengaruh terhadap minat penggunaan Youtube sebagai pembelajaran. Jika dibandingkan dengan jurnal terdahulu (Pinho dan Soares, 2011) hasil analisis hipotesis peneliti sama dengan hasil analisis hipotesis pada jurnal terdahulu yaitu variabel Attitude to Use memiliki pengaruh terhadap Behavioral Intention.

Perhitungan Goodness of Fit (GoF) menggunakan rumus sebagai berikut:

$$
\begin{aligned}
& \mathrm{GoF}=\sqrt{\overline{\mathrm{AVE} \times \overline{\mathrm{R}^{2}}}} \\
& \mathrm{GoF}=\sqrt{0,58 \times 0,47} \\
& \mathrm{GoF}=\sqrt{0,2726} \\
& \mathrm{GoF}=0,52
\end{aligned}
$$

Berdasarkan perhitungan di atas, diperoleh nilai GoF sebesar 0,52, nilai 0,52 merupakan nilai GoF besar karena $0,52>0,36$. Sehubungan dengan hal tersebut, dapat disimpulkan bahwa model secara keseluruhan fit untuk populasi dosen Universitas Telkom.

Hasil penilaian dosen Universitas Telkom mengenai Perceived Ease of Use Youtube sebagai sumber pembelajaran dianggap baik. Hasil penilaian dosen Universitas Telkom mengenai Perceived Usefulness Youtube sebagai sumber pembelajaran dianggap baik. Hasil penilaian dosen Universitas Telkom mengenai Attitude to Use atau sikap dalam menggunakan Youtube memiliki kategori baik. Hasil penilaian dosen Universitas Telkom mengenai Behavioral Intention Youtube sebagai sumber pembelajaran memiliki kategori baik. 
Berdasarkan hasil pengolahan data yang dilakukan didapatkan bahwa Perceived Ease of Use (PEU) terbukti berpengaruh terhadap Perceived Usefulness (PU). Hal ini berarti persepsi kemudahan dalam menggunakan Youtube memengaruhi persepsi kegunaan Youtube sebagai sumber pembelajaran.

Berdasarkan hasil pengolahan data yang dilakukan didapatkan bahwa Perceived Ease of Use (PEU) tidak terbukti berpengaruh terhadap Attitude to Use (ATU). Meskipun PEU tidak berpengaruh terhadap ATU, namun PEU berpengaruh terhadap ATU melalui PU. Hal ini menunjukkan bahwa PU merupakan full mediator. Dengan kata lain, persepsi kemudahan dalam menggunakan Youtube memengaruhi sikap dalam menggunakan youtube sebagai sumber pembelajaran melalui variabel persepsi kegunaan.

Berdasarkan hasil pengolahan data yang dilakukan didapatkan bahwa Perceived Usefulness (PU) terbukti berpengaruh terhadap Attitude to Use (ATU). Hal ini menunjukkan bahwa persepsi kegunaan Youtube memengaruhi sikap dalam menggunakan Youtube sebagai sumber pembelajaran.

Berdasarkan hasil pengolahan data yang dilakukan didapatkan bahwa Attitude to Use (ATU) terbukti berpengaruh terhadap Behavioral Intention (BI). Hal ini menunjukkan bahwa sikap dalam menggunakan Youtube memengaruhi minat menggunakan Youtube sebagai sumber pembelajaran.

Berdasarkan hasil pengolahan data yang dilakukan, didapatkan hasil Goodness of Fit (GoF) dari model yang digunakan termasuk dalam GoF besar. Dengan kata model ini fit untuk populasi yang diteliti. Dengan dinyatakannya model fit, maka model ini jelas menunjukkan bahwa model TAM divalidasi sebagai model yang berguna untuk mempelajari adopsi Youtube sebagai sumber pembelajaran oleh dosen Universitas Telkom sebagai pemangku kepentingan akademis di pendidikan tinggi (Chintalapati dan Daruri, 2016).

\section{KESIMPULAN}

Universitas Telkom dapat mewajibkan para civitas akademikanya untuk menggunakan Youtube sebagai sumber pembelajaran. Dikarenakan Youtube merupakan platform yang baik untuk digunakan sebagai sumber pembelajaran sesuai dengan persepsi kegunaan, persepsi kemudahan dan minat penggunaan. Universitas Telkom dapat membuat akun Youtube untuk membagikan video-video yang dapat digunakan untuk sumber pembelajaran. Universitas Telkom dapat juga mewajibkan dosen-dosennya untuk membuat konten yang berkenaan dengan mata kuliah yang diampu agar mengurangi kurangnya video referensi pada beberapa mata kuliah tertentu.

\section{DAFTAR PUSTAKA}

APJII. 2016. Survei Internet APJII 2016. Diambil dari APJII: https://apjii.or.id/content/read/39/264/ Survei-Internet-APJII-2016

Bangkara, R., P. dan Mimba, N., P., S., H. 2016. Pengaruh Perceived Usefulness dan Perceived Ease of Use pada Minat Penggunaan Internet Banking dengan Attitude toward using sebagai Variabel Intervening. E-Journal Akuntansi Universitas Udayana, Vol.16.3

Chintalapati, N. dan Daruri, V., S., K. 2016. Examination of Use of Youtube as a Learning Resource in Higher Education: Scale Development and Validation of TAM Model. Telematics and Informatics.

Hair, J., Black, W. C., Babin, B. J., \& Anderson, R. E. 2010. Multivariate Data Analysis: A Global Perspective (7th edition). New Jersey: Pearson Education, Inc.

Hartono, J. 2007. Sistem Informasi Keperilakuan. Yogyakarta: CV Andi Offset.

Haryono, S. 2017. Metode SEM untuk Penelitian Manajemen AMOS LISREL PLS. Jakarta: Luxima Metro Media.

Igracias Universitas Telkom. 2013. Kode Dosen Universitas Telkom. Diambil kembali dari Igracias: https://igracias.telkomuniversity.ac.id/ kodedosen2013.php

Pinho, J. C. M. R., dan Soares, A. M. 2011. Examining The Technology Acceptance Model in The Adoption of Social Networks. Journal of Research in Interactive Marketing, Vol 5(2/3), 116-129.

Rukmiyati, N., M., S., dan Budiartha, K. 2016. Pengaruh Kualitas Sistem Informasi, Kualitas Informasi dan Perceived Usefulness pada Kepuasan Pengguna Akhir Software Akuntansi (Studi Empiris pada Hotel Berbintang di Provinsi Bali). E-Jurnal Ekonomi dan Bisnis Universitas Udayana 5.1, 115-142.

SDM Universitas Telkom. 2018. Data Internal

Tarhini, A., Hassouna, M., Abbasi, M. S., Orozco, J. 2015. Towards the Acceptance of RSS to Support Learning: An empirical study to validate the Technology Acceptance model in Lebanon. Electronic Journal of e-learning, Vol.13 Issue 1. 
Tabel 1. Hasil Wawancara Dosen

\begin{tabular}{|c|c|c|c|c|c|}
\hline \multirow[t]{2}{*}{ Nama Dosen } & \multirow[t]{2}{*}{ Fakultas } & \multicolumn{2}{|c|}{$\begin{array}{c}\text { Jumlah video dari Youtube } \\
\text { yang digunakan untuk }\end{array}$} & \multirow{2}{*}{$\begin{array}{c}\text { Membagikan video } \\
\text { pada dosen lain ataupun } \\
\text { pada akun Youtube }\end{array}$} & \multirow{2}{*}{$\begin{array}{c}\text { Tanggal } \\
\text { wawancara }\end{array}$} \\
\hline & & Pembelajaran & Penelitian & & \\
\hline Helni Mutiarsih Jumhur & FEB & 0 & +10 & 0 & 10 Januari 2018 \\
\hline Osa Omar Sharif & FEB & +12 & +36 & +12 & 10 Januari 2018 \\
\hline Teguh Widodo & FIT & +36 & 0 & 1 & 15 Januari 2018 \\
\hline Paku Kusuma & FIK & +216 & 0 & +16 & 23 Januari 2018 \\
\hline Rahmat Fauzi & FRI & +500 & +500 & 0 & 24 Januari 2018 \\
\hline Ahmad Alma'arif & FRI & +64 & +160 & 0 & 24 Januari 2018 \\
\hline Eko Daryanto & FIF & +72 & 0 & +10 & 25 Januari 2018 \\
\hline Ali Muayyadi & FTE & +140 & +60 & +14 & 25 Januari 2018 \\
\hline Devilia Sari & FKB & +12 & 0 & +3 & 26 Januari 2018 \\
\hline
\end{tabular}

Sumber: Hasil Olahan Penulis

Tabel 2. Operasionalisasi Variabel

\begin{tabular}{ccc}
\hline Variabel & Definisi Operasioanal & Indikator \\
\hline Perce ived & Menurut Davis et al. (1989) dalam & Mudah untuk mencari video Youtube mengenai topik mata kuliah yang relevan.
\end{tabular}

Ease of Use (Rukmiyati dan Budiartha, 2016)

(Chintalapati Perceived Ease of Use (PEU)

dan Haruri, merupakan tingkat seberapa besar

2016) teknologi komputer dirasakan relatif mudah untuk dipahami dan digunakan.
Mudah untuk menavigasi video Youtube di perangkat saya.

Lancar untuk menjelajah (browsing) video Youtube menggunakan perangkat saya.

Saya menemukan video yang berguna dari beberapa topik mata kuliah pada

Usefulness (Rukmiyati dan Budiartha, 2016) Youtube.

(Chintalapati Perceived of usefulness (PU) Keberagaman konten pada Youtube memenuhi seluruh topik yang saya sukai.

dan Daruri, merupakan suatu tingkatan dimana

2016) seseorang percaya bahwa penggunaan suatu subyek tertentu akan dapat meningkatkan prestasi kerja orang tersebut.
Youtube berguna untuk memperoleh konten untuk tugas maupun pembelajaran.

Fitur pencarian yang ada pada Youtube menyediakan konten video untuk pembelajaran.

Playlist (daftar putar) yang ada pada Youtube memberikan perspektif komprehensif mengenai topik yang menarik bagi saya.

Youtube membantu saya mempelajari gagasan baru.

Youtube memiliki konten untuk belajar mandiri topik mata kuliah yang berbeda.

\begin{abstract}
A t t i t u d e Attitude (sikap) menurut Davis et al. Towards Use (1989) dalam (Bangkara \& Mimba, (Chintalapati 2016) attitude toward using (sikap dan Daruri, terhadap penggunaan) merupakan 2016) perasaan positif atau negatif dari seseorang jika harus melakukan perilaku yang akan ditentukan.
\end{abstract}

Youtube adalah alat yang bagus untuk belajar mandiri.

Saya bangga atas pembelajaran yang diraih melalui Youtube

Saya merasa senang menggunakan Youtube untuk belajar.

Youtube menyediakan materi dari lembaga-lembaga terkemuka.

Sangat menyenangkan menghabiskan waktu di Youtube.

Saya menyarankan teman saya untuk menggunakan Youtube untuk kegiatan pembelajaran mereka.

\footnotetext{
Behavioral Behavioral Intention (Minat Perilaku) Intention to Use merupakan suatu minat atau keinginan (Chintalapati untuk melakukan perilaku. Minat dan Haruri, perilaku(BI) ini belum berupa perilaku, 2016) karena perilaku itu sendiri dilakukan karena individual memiliki minat atau keinginan untuk melakukannya Saya akan menggunakan Youtube sebagai sumber pembelajaran di masa depan. Youtube telah meningkatkan performa saya dalam tugas akademik Saya ingin meningkatkan waktu yang digunakan untuk Youtube di masa depan. Saya berbagi konten untuk belajar dengan pengguna Youtube lainnya. Saya merekomendasikan konten untuk belajar kepada pengguna Youtube lainnya.

(Hartono, 2007:25-26).
} 
Tabel 3. Direct Effect

\begin{tabular}{cccccc}
\hline $\begin{array}{c}\text { Hipo- } \\
\text { tesis }\end{array}$ & $\begin{array}{c}\text { Direct } \\
\text { Effect }\end{array}$ & $\begin{array}{c}\text { Path } \\
\text { Coeffi- } \\
\text { cients }\end{array}$ & $\begin{array}{c}\text { T-Sta- } \\
\text { tistic }\end{array}$ & $\begin{array}{c}\text { Signifi- } \\
\text { kansi }\end{array}$ & Kesimpulan \\
\hline H1 & PEU $\rightarrow$ PU & 0,69 & 13,17 & $>1,96$ & Terbukti \\
H2 & PEU $\rightarrow$ ATU & 0,07 & 0,73 & $>1,96$ & Tidak Terbukti \\
H3 & PU $\rightarrow$ ATU & 0,58 & 6,38 & $>1,96$ & Terbukti \\
H4 & ATU $\rightarrow$ BI & 0,76 & 19,98 & $>1,96$ & Terbukti \\
\hline
\end{tabular}

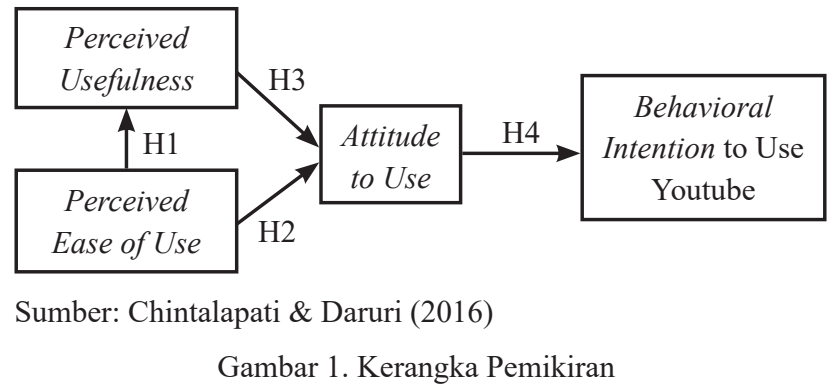

